http://journal.uin-alauddin.ac.id/index.php/lamaisyir

\title{
THE INTERNALIZING VALUE OF THE LEMPU' REFIEL THE BUSINESS BENEFITS OF MIXED TRADERS' PERSPECTIVE OF ISLAMIC BUSINESS ETHICS
}

\author{
Nani Hamdani Amir ${ }^{1}$, Irwan Misbach ${ }^{2}$, dan Abdul Wahid Haddade ${ }^{3}$ \\ Pascasarjana Universitas Islam Negeri Alauddin Makassar \\ Jl. HM Yasin Limpo No.36, Samata-Gowa \\ nanihamdani7@gmail.com¹, irwan.misbach@uin-alauddin.ac.id², \\ wahid.haddade@uin-alauddin.ac.id ${ }^{3}$ \\ Received: 27 Januari 2020; Revised: 21 Desember 2020; Published: 30 Desember 2020
}

\begin{abstract}
ABSTRAK
Penelitian ini bertujuan untuk menginternalisasi nilai lempu' dalam mengungkap keuntungan usaha pedagang campuran perspektif etika bisnis Islam. Fokus penelitian ini pada nilai lempu' dalam budaya siri'na pacce dan prinsip-prinsip etika bisnis Islam. Jenis penelitian kualitatif dengan pendekatan etnografi dan teologis normatif. Sumber data dalam penelitian ini adalah data primer yang diperoleh langsung dari tempat penelitian dengan wawancara para pedagang campuran yang bersuku Bugis-Makassar. Hasil penelitian menjelaskan nilai lempu' yang bermakna kejujuran, kebenaran, keikhlasan, kebaikan, dan keadilan membentuk karakter sebagian besar pedagang bersuku Bugis-Makassar untuk berperilaku sesuai dengan budayanya. Nilai lempu' dalam budaya suku BugisMakassar ini memiliki makna yang sama dengan prinsip-prinsip etika bisnis Islam yaitu tauhid, keseimbangan, kebenaran, dan ihsan. Penerapan nilai lempu' dan prinsip etika bisnis Islam dalam berdagang menghasilkan tidak hanya keuntungan materi semata, tetapi keuntungan non materi berupa keberkahan yaitu ketenangan jiwa dan tidak semakin jauh dengan Allah swt yang membawah kepada kesejahteraan dunia dan akhirat.
\end{abstract}

Kata Kunci: Internalisasi; Nilai lempu'; Keuntungan.

\begin{abstract}
This study aims to internalize the value of lempu' in uncovering the advantages of mixed traders with Islamic business ethics perspectives. The focus of this research is on the values of lempu' contained in the siri'na pacce culture and the principles of Islamic business ethics. Researchers used qualitative methods with normative ethnographic and theological approaches. Sources of data in this study are primary data obtained directly from the research site with interviews by mixed traders of Bugis-Makassar ethnicity through direct face-to-face. The results explain that the value of lempu' means honesty, truth, sincerity, kindness, and justice shape the character of most of the Bugis-Makassar traders to behave according to their culture. The value of lempu' in the Bugis-Makassar ethnic culture has the same meaning as the principles of Islamic business ethics, namely monotheism, balance, truth, and ihsan. The application of the value of lempu' and the principles of Islamic business ethics in trading yields not only material benefits, but nonmaterial benefits in the form of blessings for peace of mind and does not make it further away from God which brings to the welfare of the world and the hereafter.
\end{abstract}

Keywords: Internalization; Lempu' value; and benefits 


\section{PENDAHULUAN}

Islam suatu agama universal yang telah membahas segala aspek kehidupan utamanya dalam berdagang. Aktivitas berdagang tujuan utama memperoleh keuntungan guna mempertahankan keberlangsungan hidup. Pandangan Islam mengenai keuntungan dianggap rezeki yang diberikan Allah swt, bukan hanya segi materil semata namun keuntungan non materi berupa keberkahan (Barus, 2016).

Keuntungan materi yaitu berupa uang yang didapatkan dari hasil berdagang dan keuntungan non materi berupa keberkahan (Nasution, 2018). Keuntungan materi sangat penting untuk dicari, namun keuntungan non materi berupa berkah lebih penting karena dapat membawah kepada ketenangan jiwa dalam menjalani kehidupan dan tidak membuat semakin jauh dengan Allah swt. Selain itu, dengan keberkahan mencegah bersikap sombong dan menjadikan tunduk kepada sang pemberi rezeki Allah swt (Ubaidillah et al., 2013).

Fenomena sekarang ini, pedagang menjadikan keuntungan materi menjadi tujuan utama dalam berdagang, walaupun harus dengan cara curangan. Namun bukan menjadi alasan untuk melakukan tindakan kecurangan dalam berdagang. Kecurangan yang sering terjadi seperti mengurangi timbangan (Khairunisa, 2019). Melakukan penimbunan dengan menyimpanan barang dagangan dengan segaja sampai batas waktu tertentu dengan menunggu tinggi sharga barang yang ditimbun untuk mendapatkan keuntungan yang lebih besar. Hal ini dalam perdagangan Islam tidak diperbolehkan terjadi (Rusydi et. al, 2018). Sebagaimana pandangan kapitalis berasumsi keuntungan materil utama dalam berdagang.

Islam tidak memberikan batasan kepada para pedagang untuk memperoleh keuntungan, hanya saja memiliki batasan yang sesuai dengan prinsip etika bisnis Islam. Batasan berdagang dalam etika bisnis Islam yang mempengaruhi perilaku pedagang. Adanya batasan etika bisnis Islam dalam berdagang dapat membatasi permasalahan yang terjadi di dalam berdagang. (Lalu Muh Shabiran dan Titiek Herwanti, 2017). Peneliti sebelumnya menjelaskan bahwa memberikan pemahaman etika bisnis Islam dalam ruang lingkup berdagang semakin mendorong para pedagang melakukan tindakan sesuai prinsip syariah Islam terutama kejujuran. Sehingga, para pedagang menyadari konsep etika bisnis Islam membawah kepada kebahagian dunia dan akhirat karena mendapatkan keberkahan dari Allah swt. 
Etika yang berasal dari bahasa Yunani 'ethos', berarti timbul dari kebiasaan, karakter, atau sekumpulan perilaku moral yang diterima secara luas (Sulkifli Herman, Nasir Hamzah, 2018). Sedangkan dalam bahasa arab 'akhlak' bentuk jamak dari mufrodnya ' $k h u l u q$ ' artinya 'budi pekerti' diartikan kebiasaan atau adat istiadat yang merujuk kepada perilaku manusia itu sendiri, tindakan atau sifat yang dianggap benar.

Bisnis adalah dalam bahasa Inggris "buying and selling; commerce; trade yang berarti jual beli, perniagaan, dan perdagangan. Kata bisnis dalam bahasa Arab al-tijarah yang berarti berdagang/perniagaan (Fauzan dan Ida Nuryana, 2014). Secara umum bisnis merupakan suatu aktivitas dari berbagai transaksi yang dilakukan seseorang guna menghasilkan keuntungan untuk memenuhi kebutuhan hidupnya.

Etika bisnis Islam merupakan proses mengetahui hal-hal yang benar dan yang salah untuk melakukan aktivitas berbisnis atau berdagang sesuai prinsip syariah Islam guna menghasilkan keuntungan. Konsep etika bisnis Islam membawah dua keuntungan bagi pelakunya yakni dunia dan diakhirat karena bersumber dari al-Qur'an dan hadis yang menjadi pedoman umat Islam (Hulaimi, 2017).

Etika bisnis Islam berlandaskan al-Qur'an yang dijadikan sumber dari segala sumber yandg dijadikan pedoman dalam kehidupan umat Islam. Islam secara jelas menganjurkan umatnya untuk berusaha mencari rezeki dimuka bumi yang menjadi bekal hidupnya di dunia dalam menopang ibadahnya kepada Allah swt. Segala sumber daya yang ada bumi ciptaan Allah swt, manusia diberikan amanah untuk mengelola dan memanfaatkannya demi mencapai kesejahteraan lahir dan batin, sebagaimana firman Allah swt dalam dalam QS. an-Nisa/4:29:

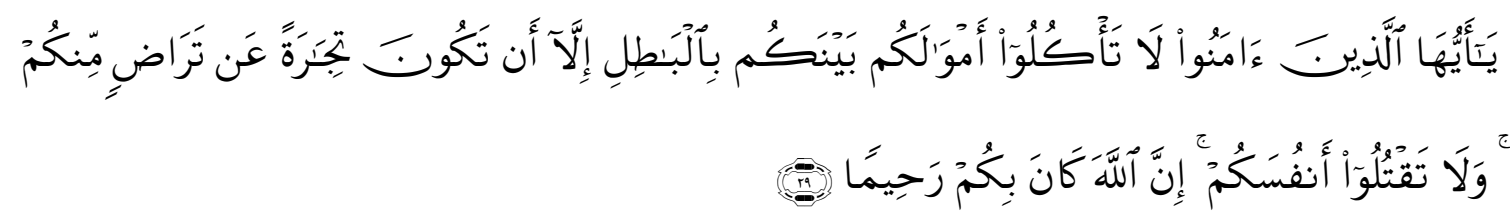

Terjemahnya:

Hai orang-orang yang beriman, janganlah kamu saling memakan harta sesamamu dengan jalan yang batil, kecuali dengan jalan perniagaan yang berlaku dengan suka sama-suka di antara kamu. Dan janganlah kamu membunuh dirimu. Sesungguhnya Allah adalah Maha penyayang kepadamu. 
Ayat telah dijelaskan setiap manusia diberikan kebebesan untuk melakukan kegiatan berbisnis/berdagang namun harus sesuai dengan prinsip Islam. Mulai dari mengelola sumber daya alam dengan cara mendistribusikan dengan adil sampai dengan memperoleh keuntungan sebesar-besarnaya. Allah swt memberikan kebebasan itu semua namun harus sesuai dengan prinsip syariah Islam.

Prinsip etika bisnis Islam yang sesuai dengan syariah Islam memiliki enam prinsip tauhid, tujuan utama manusia segala aktivitasnya adalah beribadah kepada Allah swt, maka manusia dalam melakukan aktivitas berbisnis atau berdagang semestinya harus selalu mengingat Allah swt. Untuk itu yang menjadi proritas utama beribadah kepada Allah swt (Mukaffa, 2018).

Prinsip keseimbangan, prinsip ini dalam aktivitas berdagang sama halnya dengan berbuat adil. Adil berati sama berat, tidak berat sebelah, tidak memihak, serta berpihak kepada kebenaran. Perdagangan persyaratan adil yang paling mendasar adalah dalam menentukan mutu (kualitas) dan ukuran (kuantitas) pada setiap takaran dan timbangan. (Zainuddin \& Isa, 2019)."

Prinsip kehendak bebas, prinsip yang membebaskan manusiaa mengelola sumber daya alam dengan baik yang menjadi wakil Allah swt di bumi sebagai khalifah. Konsep perdagangan prinsip kehendak bebas memberikan kebebasan bersaing terutama dalam pasar tanpa ada intervensi dari pihak mana pun tanpa terkecuali, seperti bentuk monopoli, kecurangan, dan praktik riba (Rosiyana et al., 2017).

Prinsip tanggung jawab, hal mendasar yang berkaitan dengan kebebasan ekonomi, segala kebebasan dalam melakukan bisnis/berdagang oleh manusia tidak lepas dari tanggung jawab. Artian tanggung jawab kepada Allah swt ketika melakukan yang tidak sesuai dengan prinsip syariah Islam. (Juliyani, 2016).

Prinsip Kebenaran, mengandung dua unsur yaitu kebajikan dan kejujuran. Konteks bisnis, kebenaran dimaksudkan sebagai niat, sikap, dan perilaku benar yang meliputi proses akad (transaksi), proses mencari atau memperoleh komoditas pengembangan ataupun dalam proses upaya meraih atau metapkan keuntungan (Norvadewi, 2015). Kejujuran dalam berbisnis/berdagang sangat penting dan harus diterapkan. Jika seorang pebisnis jujur, maka usahanya lancar dan diberkahi oleh Allah swt. Keberkahan dalam setiap rezeki yang diperoleh sangat penting artinya, karena jujur merupakan salah satu kunci kesuksesan dalam berusaha.

Prinsip ihsan, berarti melaksanakan perbuatan baik yang dapat memberikan kemanfaatan kepada orang lain, tanpa adanya kewajiban tertentu 
yang mengharuskan perbuatan tersebut atau dengan kata lain beribadah dan berbuat baik seakan-akan melihat Allah (Fajaruddin \& Hania, 2018).

Penerapan etika bisnis Islam dalam keseharian para pedagang tidak hanya dipengaruhi oleh konsep Islam semata, namum dipengaruhi nilai-nilai budaya dalam kehidupannya yang telah menjadi jati diri sebuah suku didaerah tertentu (Bahar \& Teng, 2017). Di Sulawesi Selatan misalnya terdapat suku BugisMakassar memiliki nilai lempu' merupakan bagian dari budaya siri'na pacce yang dijadikan pandangan hidup masyarakatnya yang telah lama dipraktikan (Tri Tarwiyani, 2012). Nilai budaya sudah sangat mendarah daging dalam jiwa dan sukma orang Bugis-Makassar dan semakin tinggi nilai budaya leluhur dalam pikiran, hati dan perbuatan, semakin tinggi pula kadar kemulian manusia (Sewang et al., 2020).

Kejujuran dimaknai dalam pemahaman lempu' yaitu: tidak berbohong, baik, adil, dan benar (Faisal, 2016). Nilai lempu' dalam budaya siri'na pacce dalam maknanya begitu sejalan dengan prinsip etika bisnis Islam, sehingga menjadi acuan peneliti mengeskplorasi lebih dalam nilai budaya agar dapat diinternalisasikan dengan etika bisnis Islam. Nilai lempu' dan etika bisnis Islam dapat diterapkan para pedagang(Azis et al., 2015).

Lempu' jika diinterpretasi lebih jauh memiliki cakupan yang luas. Lempu' dilihat dalam dimensi perkataan (lisan) dan dimensi tindakan/perilaku berarti menempatkan sesuatu pada tempatnya. Selain itu lempu' juga dikonotasikan tidak berbohong (dalam dimensi perkataan) atau tidak mengatakan yang tidak sesuai dengan kenyataannya. Dimensi tindakan, lempu' berarti menempatkan sesuatu pada tempatnya dan tidak mengambil yang bukan haknya atau bukan miliknya sehingga dapat dikatakan bahwa kejujuran adalah mutiara yang terpendam dalam jiwa (Ilman \& Rusdi, 2015).

Tujuan penulisan adalah untuk menganalisis internalisasi nilai lempu' dan prinsip-prinsip etika bisnis Islam pada pedagang campuran di pasar Panakukkang Makassar dapat diterapkan dalam berdagang agar tidak melakukan tindakan kecurangan. Hal ini dilakukan agar tidak terjadi kecurangan dalam berdagang di pasar dan mendapat keuntungan yang tidak hanya berupan materi tetapi keuntungan non materi berupa keberkahan. Selain itu, ingin mengangkat nilai budaya suku Bugis-Makassar yang telah mulai tergerus oleh budaya baru. 


\section{METODE PENELITIAN}

Jenis penelitian yang digunakan adalah penelitian kualitatif. Lokasi penelitian dilakukan di pasar Panakkukang yang beralamat Jl. Toddopuli Raya, Kelurahan Paropo, Kecamatan Panakkukang, Kota Makassar, Provensi Sulawesi Selatan. Pendekatan yang digunakan dalam penelitian ini adalah pendekatan etnografi dengan berfokus pada makna sosiologi dengan menggambarkan, menganalisis dan memberikan penafsiran dari sebuah pola budaya tertentu dan pendekatan teologis normatif dengan menggunakan ketentuan-ketentuan hukum syariah Islam yang berlaku. Adapun sumber data dalam penelitian ini adalah data primer yang diperoleh langsung dari tempat penelitian dengan wawancara langsung oleh para pedagang campuran yang bersuku BugisMakassar di pasar panakkukang Makassar melalui tatap muka langsung. Metode pengumpulan data yaitu observasi berupa pengamatan yang dilakukan peneliti, wawancara yang dilakukan peneliti terkait penelitian, dan dokumentasi yang menjadi pelengkap dalam penelitian. Teknik pengelolaan data yang dilakukan yaitu reduksi data, penyajian data, dan penarikan kesimpulan. Teknik analisis data dengan mencari dan menyusun secara sistematis melalui catatan observasi, wawancara, dokumentasi untuk meningkatkn pemahaman peneliti mengenai kasus yang diteliti dan menyajikannya sebagai temuan dari penelitian.

\section{HASIL PENELITIAN DAN PEMBAHASAN}

\section{Internalisasi Nilai Lempu' Dalam Mengungkap Keuntungan Usaha Pedagang Campuran Perspektif Etika Bisnis Islam}

Pasar Panakkukang merupakan salah satu pasar tradisional yang berada di Kota Makassar, tepatnya berada di wilayah Kelurahan Paropo, Kecamatan Panakkukang, Kota Makassar, Provinsi Sulawesi Selatan. Berbagai pedagang berada di pasar Panakkukang, menjadi objek informan peneliti para pedagang campuran yang menjual berbagai dagangan seperti beras, telur, cabe, tomat, kentang, wartel, mie, gula, garam, dan miyak goreng. Para pedagan campuran yang menjadi informan bukan hanya beragama Islam, namun bersuku BugisMakassar yang merupakan suku asli Sulawesi Selatan. Seorang pedagang di pasar campuran menjelaskan mengenai makna lempu' yang diterapkan dalam berdagang yang menurutnya sejalan dengan etika bisnis berbasis Islam. Panakukkang dilakukan Abdul Rasyid dalam berdagang bahwa:

Menurut Abdul Rasyid (2019) “Lempu' atau kejujuran modal utama dalam berdagang, ketika barang rusak baru dijual ki bukan malah 
mendatangkan keuntungan tetapi malah akan membuat masiri' karena di bohongi pelanggan dan tidak berkah juga dirasakan. Berkah yang dirasakan tidak bisa diukur dengan apapun dan hanya bisa dirasakan seperti mendapatkan kesehatan, ketenangan jiwa, umur yang panjang karena bukti taat sama Tuhan. Jadi sikap lempu' itu harus ada dalam diri pedagang apalagi suku Bugiski ada rasa siri' ta".

Pedagang memahami bahwa dalam berdagang kejujuran menjadi modal utama untuk mendatangkan keuntungan pada dirinya. Keuntungan yang didapatkan tidak hanya berupa keuntungan materi, namun keuntungan non materi berupa keberkahan yaitu dengan mendapatkan kesehatan, ketenagan jiwa, dan umur yang panjang dan merupakan bukti ketaatanya kepada Allah swt. Apalagi kejujuran itu telah diajarkan dalam budayanya sejak dahulu yang dikenal dengan istilah lempu', sehingga membuat mereka menerapkan kejujuran dalam berdagang.

Menurut Suryadi (2019) “Lempu' atau kejujuran ini perlu ditegakkan dalam berdagang, karena merupakan kunci utama dalam berdagang. Apalagi kalau curangki dengan mengurangi timbangan atau liter beras tidak mau mi lagi pembeli belanja ditempat ta. Kalau tidak diterapkan sikap lempu' sedikit yang beli di tempat ta dan tidak ada jih juga keberkahaan di dapat. Tidak tenang perasaan dirasa karena berbohongki sama pembeli dan itu pasti di ingat terus.

Pedagang menjelaskan lebih mendalam makna lempu' yaitu tidak hanya memahami sebagai kejujuran semata, namun mehami sebagaimana kejujuran itu sebagai bentuk tidak melakukan tindakan kecurangan dengan tidak melakukan pengurangan timbangan sebagaimana dalam prinsip keseimbangan dalam etika bisnis Islam. Menurut pedagang ketika melakukaan hal kecurangan ada perasaan malu yang dirasakan dan hal ini yang sangat tidak mencerminkan sebagai suku Bugis-Makassar yang memegang teguh nilai budayanya sejak dahulu kalah. Hal ini dilakukan untuk tetap mempertahankan budayanya dan mendapatka keberkah dari Allah swt.

Menurut Hasna (2019) 'Lempu' atau kejujuran itu penting dalam berdagang karena bukan perasaan malu yang dirasakan sama pembeli tapi tanggung jawab kepada yang Maha Kuasa di akhirat, contohnya dalam timbangan/liter dikurangi selain merasa berdosaki sama yang Maha Kuasa dengan pembeli juga tidak mau lagi belanja di tempat ta. Tidak ada juga berkahnya didapat kalau dibohongi pembeli karena berkah itu hanya kita yang rasa ada ketenangan, kesehatan yang diberikanki, berkat kita ikuti yang Maha kuasa perintahnya dalam berdagang. Apalagi soal timbangan bukan hanya didunia di dapat sampai di akhirat. Hal seperti ini juga sejak lama mi kita 
terapkan sudah menjadi budaya mi dalam diri apalagi bersuku bugiski kejujuran yang dijunjung tinggi".

Kejujuran atau lempu' menurutnya penting karena bukan hanya persoalan perasaan malu kepada pembelinya semata tetapi perasaan takut kepada Allah swt ketika melakukan tindakan kecurangan. Apabila melakukan tindakan kecurangan tanggung jawab di akhirat mereka memikirkan dan keberkahan dari keuntungaan yang didapatkaan tidak akan dirasakan akibat dari perilaku yang tidak jujur yang dilakukan. Selain itu, pedagang masih memegang teguh budayanya yang telah ada. Hal ini menjelaskan bahwa prinsip tauhid dalam etika bisnis Islam berperan terhadap perilaku pedangang untuk tidak melakukan tindakan kecurangan dan berkaitan erat dengan nilai budaya lempu' dalam suku Bugis-Makassar yang menjadi pedoman dalam kehidupan terutama dalam hal berdagang.

Menurut H. Mardani (2019) “Lempu' atau jujur dalam berdagang harus sesuai apa yang dikatakan mulai dari timbangan/liter dan kualitas barang disampaikan kepada pembeli, supaya tidak malu-maluki kalau ada datang pelanggan yang komplen karena merasa bilang di bohongi. Selain itu juga melakukanki kebohongan itu perilaku tidak baik, tapi kalau melakukan ki kejujuran suatu hal yang baik dan pasti Allah melihat itu semua yang dilakukan. Diakhirat didapat semua ganjarannya, didunia juga didapat tidak ada barokkana karena keuntungan didapat dari hasil kebohongan. Nah itu semua tidak ada manfaat yang dirasakan dari berdagang. Makanya kejujuran itu penting dan sebagai suku Bugis-Makassar harus menjunjung tinggi karena nenek moyang kita dulu rata-rata pedagang dan apa yang membuat mereka sukses karena kejujuran dan berdagang itu niatnya karena Allah. Itulah yang harus kita jaga sebagai penerusnya.

Lempu' atau kejujuran penting dalam berdagang, apalagi dalam hal timbangan dan kualitasnya barang dagangan harus jujur. Karena ada Allah swt yang melihat ketika melakukan hal kebaikan dan bermanfaat dan keburukan. Melakukan hal kebaikan dalam berdagang alan mendapatkan manfaat keuntungan materi dan kepercayaan, namun keberkahan dunia dan akhir. Selain keuntungan materi dan non materi didapatkan dari bentuk kejujuran ini yaitu menjaga nilai budaya dari suku Bugis-Makassar yang telah lama diterapkan oleh para nenek moyang yang menjadi kesuksesan.

\section{Internalisasi Nilai Lempu' dan Prinsip Etika Bisnis Islam}

Hasil internalisasi nilai lempu' dalam budaya siri'na pace dan prinsip etika bisnis Islam untuk mengungkap keuntungan usaha pedagang campuran di 
pasar Panakkukang Makassar menunjukkan ada kesamaan makna kebaikan yang terkandung didalamnya, dapat dilihat dalam gambar berikut:

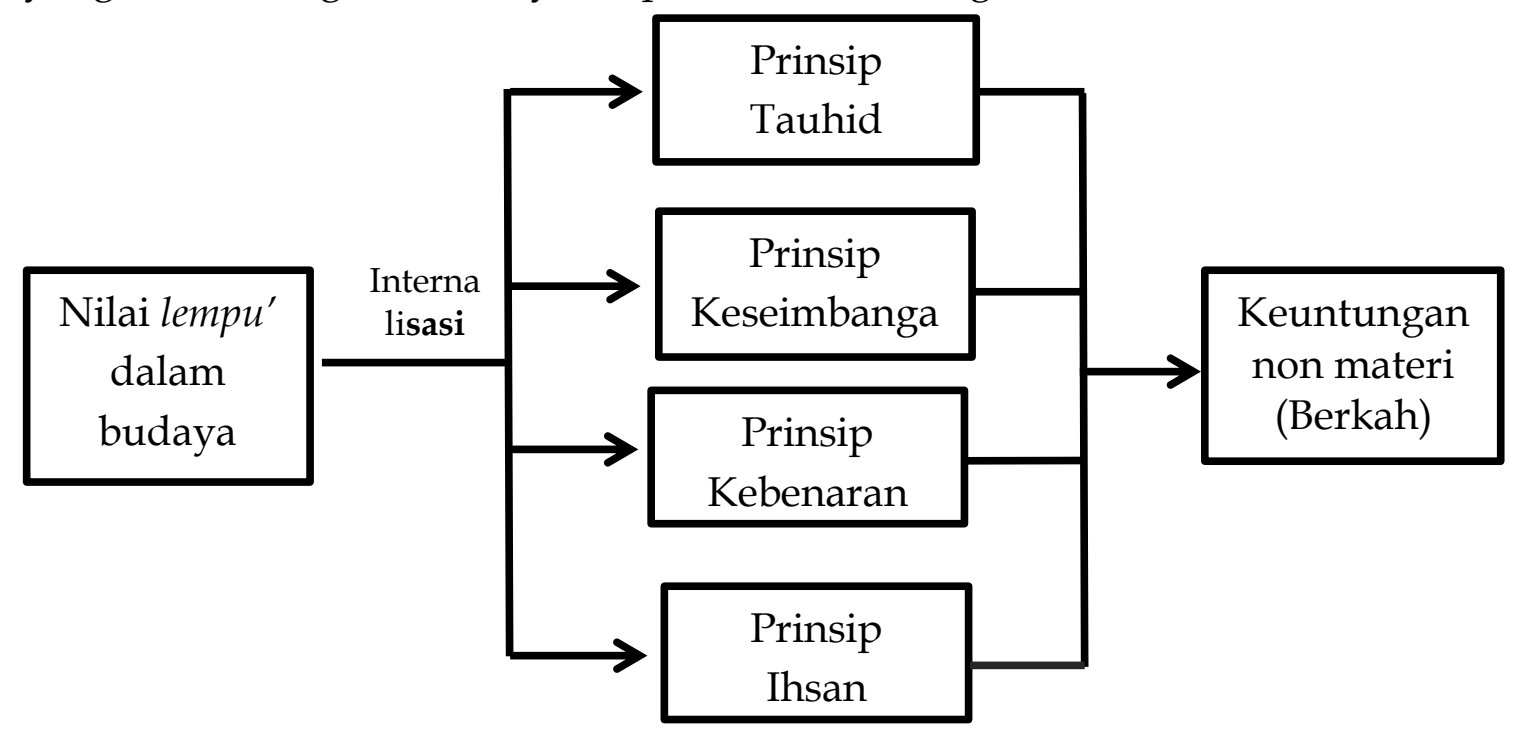

Gambar 1. Internalisasi nilai lempu' dan etika bisnis Islam

Nilai lempu' di internalisasikan dengan prinsip tauhid dalam kegiatan berdagang yaitu menempatkan Allah swt sebagai tujuan utama dalam setiap aktivitas yang dilakukan dalam berdagang. Keseharian pedagang walaupun sibuk aktivitas berdagang dipasar tetapi melaksanakan ibadah yang menjadi hal utama sebagai bukti Mengingat Allah swt dalam segala aspek kehidupan terutama dalam berdagang, membawa manusia untuk selalu berbuat jujur karena takut dengan Allah swt untuk melakukan kebohongan yang dapat merugikan orang lain dan dirinya sendiri. Kerugian diri sendiri berupa sangsi sosial yaitu kepercayaan dalam berdagang sudah hilang mengakibatkan keuntungan berkurang dan mempertanggung jawabkan kelak diakhirat dihadapan Allah swt atas diperbuatnya.

Nilai lempu' diinternalisasikan dengan prinsip keseimbangan yaitu selalu berbuat adil dan berkata yang benar sesuai apa yang terjadi. Prinsip keseimbangan ini, keseharian pedagang melakukan prinsip keseimbangan dari segi timbangan dan takaran harus sesuai tidak boleh kurang, serta dari segi kualitas barang para pedagang menjaga kualitas barang yang dijualnya, kalau rusak dibuang dan tidak boleh dijual lagi. Timbangan dan takaran sesuai, serta kualitas barang terjamin, dilakukan semata-mata ingin mendapatkan keberkahan dari Allah swt berupa kesejahteraan dunia dan keselamatan akhirat. Tidak melakukan tindakan kebohongan dalam timbangan dan kualitas barang, melakukan kejujuran karena takut dengan Allah swt. 
Nilai lempu' diinternalisasikan dengan prinsip kebenaran mengandung makna kebaikan dan kejujuran yang dimiliki. Hal kejujuran para pedagang menempatkan kejujuran adalah modal utamanya dari segi apapun harus melakukan kejujuran, baik dari segi timbangan/takaran, kualitas barang bahkan dari segi harga jual barang sebenarnya dikatakan kepada para pembeli. Seorang pedagang jujur, usahanya lancar dan diberkahi Allah swt. Keberkahan rezeki yang diperoleh serta kebahagian dunia dan akhirat dirasakan pedagang atas kejujuran yang dilakukannya.

Nilai lempu' diinternalisasikan dengan prinsip ihsan merupakan selalu melakukan hal yang bermanfaat untuk orang lain, karena selalu menyakini bahwa setiap apa yang dilakukan pasti Tuhan melihatnya. Keseharian pedagang dalam hal ini menerapkan kejujuran untuk timbangan/takaran dan kualitas barang selalu dijaga seolah Allah swt melihat apa yang dilakukan. Pedagang tidak dapat melakukan kecurangan dalam aktivitas berdagang.

Hasil penelitian yang dilakukan oleh peneliti terhadap informan menunjukan bahwa suku Bugis-makassar menempatkan nilai kejujuran hal utama dalam setiap aktifitasnya terutama dalam hal berdagang. Berdagang nilai utamanya yaitu kejujuran yang menjadi kuncinya untuk mendapatkan keuntungan. Keuntungan yang didapatkan yaitu keuntungan materi dan keuntungan non materi berupa keberkahan. Keberkahan inilah yang banyak dirasakan oleh pedagang campuran di pasar Panakukkang. Keberkahan yang dirasakan pedagang membawahnya kepada ketenangan jiwa dalam menjalani kehidupan dan tidak membuat semakin jauh dengan Allah swt. Selain itu, dengan keberkahan menjadikan tunduk kepada sang pemberi rezeki Allah swt. Walaupun keuntungan yang didapatkan secara materi berkurang namun terasa banyak jika berkah dan manfaat yang luar biasa yang dirasakan dan keberkah itulah yang tidak dapat diukur dari kejujurannya dalam berdagang.

Kejujuran dalam berdagang menjadi tujuan utama untuk mendapatkan keuntungan keberkahan. Hal ini sejalan dengan makna yang terkadung dalam nilai lempu' tidak bertentangan dengan prinsip syariah Islam apalagi diinternalisasikan dalam etika bisnis Islam. Nilai lempu' dengan etika bisnis Islam dalam aktivitas keseharian berdagang di pasar Panakkukang pada prinsipnya memahami cara perdagang dalam konteks Islam dengan menerapkan prinsip kejujuran, seperti jujur dalam kualitas barang dengan menjelaskan kepada pembeli bahwa barang rusak dan barang berkualitas bagus, jujur dalam hal segi timbangan/takaran harus sesuai, jujur dalam harga pokok dari barang yang dijual, serta selalu merasa setiap aktivitas yang dilakukan dalam berdagang 
seolah-olah Allah swt melihat apa yang dilakukanya. Sehingga untuk melakukan kecurangan dalam berdagang tidak dilakukan karena takut kepada Allah swt dan menyadari bahwa yang didapatkan dalam berdagang ada hak orang lain yang harus diberikan agar terjadi keseimbangan.

Berdasarkan penjelasan dipahami bahwa Islam dan budaya tidak bertentangan, selama keduanya dipahami mengandung nilai-nilai kebaikan. Prinsip syariah Islam dapat melahirkan nilai-nilai budaya yang Islami dalam internalisasi nilai budaya kedalam etika bisnis Islam dilihat kesamaanya dapat diterapkan dalam perdagangan menghasilkan keuntungan dan nilai budaya juga masih tetap terjaga dan tidak tergerus oleh masuknya budaya baru yang merusak tatanan kehidupan dan tidak sesuai dengan prinsip syariah Islam.

\section{KESIMPULAN}

Internalisasi nilai lempu' dengan etika bisnis Islam mengandung makna prinsip tauhid yaitu menempatkan Tuhan sebagai suatu tujuan utama dalam setiap aktifitas berdagang, prinsip keseimbangan yaitu selalu berbuat adil dan berkata yang benar sesuai apa yang terjadi dalam berdagang, prinsip kebenaran mengandung makna kebaikan dan kejujuran yang dimiliki bagi pedagang modal utamanya, dan prinsip ihsan merupakan selalu melakukan hal yang bermanfaat untuk orang lain, karena selalu menyakini bahwa setiap apa yang dilakukan pasti Tuhan melihatnya. Para pedagang dapat menghasilkan keuntungan materi serta non materi berupa keberkahan yang dirasakan berupa ketenangan jiwa dalam menjalani kehidupan dan tidak membuat semakin jauh dengan Allah swt dan menjadikan tunduk kepada sang pemberi rezeki Allah swt yang hanya bisa dirasakan sendiri dan membawah kepada kesejahteraan dunia dan akhirat. Serta nilai budaya juga masih tetap terjaga dan tidak tergerus oleh masuknya budaya baru yang merusak tatanan kehidupan dan tidak sesuai dengan prinsip syariah Islam.

\section{DAFTAR PUSTAKA}

Azis, N. A., Mangoting, Y., \& Lutfillah, N. Q. (2015). Memaknai Independensi Auditor dengan Keindahan Nilai-Nilai Kearifan Lokal Siri' Na Pacce. Jurnal $\begin{array}{lll}\text { Akuntansi Multiparadigma, } & \text { 6(1), }\end{array}$ https://doi.org/10.18202/jamal.2015.04.6012

Bahar, H. M., \& Teng, A. (2017). Filsafat Kebudayaan Dan Sastra (Dalam 
Perspektif Sejarah). Jurnal Ilmu Budaya, 5(1), 2354-7294.

Barus, E. E. ; N. (2016). Implementasi etika bisnis islam (Studi pada rumah makan wong solo Medan). Perspektif Ekonomi Darussalam, Vol 2(No 2), 125-146. https://doi.org/Barus, E. E. ; N. (2016). Implementasi Etika Bisnis Islam ( Studi Pada Rumah Makan Wong Solo Medan ). FEBI UIN Sumatera Utara, Vol 2(No 2), Hal 125-146.

Faisal, A. (2016). Budaya Siri' dan Pesse' dalam Bingkai Akuntansi Makassar. Kuriositas, 2(8), 19-30. http://ejurnal.stainparepare.ac.id/index.php/kuriositas/article/view/72 $/ 67$

Fajaruddin, A., \& Hania, B. T. (2018). Business System Analysis Based On Multi Level Marketing In The Perspective of Islami Business Ethics (Case Study: PT. Veritra Sentosa International). Islamic Economics Journal, 4(1), 19. https://doi.org/10.21111/iej.v4i1.2897

Fauzan dan Ida Nuryana. (2014). Pengaruh penerapan etika bisnis terhadap kepuasan pelanggan warung bebek H. Slamet di Kota Malang. Modernisasi, 10(1), 38-55.

Hulaimi, A. (2017). Etika bisnis islam dan dampaknya terhadap kesejahteraan pedagang. Jurnal Ekonomi Dan Bisnis Islam, 2(1), 17-31.

Ilman, M., \& Rusdi, W. (2015). Nilai Budaya Siri' Na Pacce Dan Perilaku Korupsi. Jurnal Indigenous, 13(2), 68-86.

Juliyani, E. (2016). Etika Bisnis dalam Persepektif Islam. Jurnal Ummul Qura, VII(1), 63-74.

Khairunisa, P. N. (2019). Etika Bisnis Dalam Islam Terhadap Transaksi Terlarang Riba dan Gharar. Jurnal Ilmu Ekonomi Islam, 3(1), 81-95.

Lalu Muh Shabiran dan Titiek Herwanti. (2017). Etika bisnis pedagang pada jual beli telepon genggam bekas ditinjau dari perspektif ekonomi islam. Maqdis Kajian Ekonomi Islam, 2(1), 80-92.

Mukaffa, Z. (2018). The Era Of Uncertainty And Ethical Arrangement In Javanese Classical Disseminating Ranggawarsita' s Works as Source of Islamic Ethics in Islamic Higher Education. 56(2), 461-493. https://doi.org/10.14421/ajis.2018.562.461-493

Nasution, A. M. (2018). Batasan Mengambil Keuntungan Menurut Hukum Islam. 
Jurnal El-Qanuniy: Jurnal Ilmu-Ilmu Kesyariahan Dan Pranata Sosial, 4(1), 88100. https://doi.org/10.24952/el-qonuniy.v4i1.1829

Norvadewi. (2015). Bisnis Dalam Persfektif Islam (Telaah Konsep, Prinsip dan Landasan Normatif). Jurnal Ekonomi Dan Bisnis Islam, 1(1), 33-46.

Rosiyana, L., Arifin, Z., \& Sunarti. (2017). Implementasi Etika Bisnis Islam Guna Membangun Bisnis Yang Islami (Studi pada Waroeng Steak And Shake Cabang Malang). Jurnal Administrasi Bisnis (JAB), 53(1), 196-201.

Rusydi, B. U., Ihsan, M., \& Abdullah, W. (2018). Implementasi Prinsip Ekonomi Islam Oleh Pedagang Dalam Melakukan Penimbangan Sembako Di Pasar Soppeng. An-Nisbah: Jurnal Ekonomi Syariah, 5(1), 434-456. https://doi.org/10.21274/an.2018.5.1.399-414

Sewang, A. M., Husain, M. Z., \& Kurniawan, C. S. (2020). Pasang Ri Kajang In Developing Youth Character Of Environmental Love In Tana Toa KajangA. Jurnal Adabiyah, 20(1).

Sulkifli Herman, Nasir Hamzah, dan A. K. (2018). Prinsip Dan Etika Pada Manajemen Pemasaran Dalam Upaya Pengmbangan Bisnis Thaybah Mart. Laa Maisyir, 5(2), 1-23.

Syarif, E., Sumarmi, S., \& Astina, I. K. (2016). Integrasi Nilai Budaya Etnis Bugis Makassar Dalam Proses Pembelajaran Sebagai Salah Satu Strategi Menghadapi Era Masyarakat Ekonomi Asean (MEA). Jurnal Teori Dan Praksis Pembelajaran IPS, 1(1), 13-21. https://doi.org/10.17977/um022v1i12016p013

Tri Tarwiyani. (2012). Nilai Nilai Hukum Masyarakat Bugis Makassar - Jurnal Filsafat UGM.pdf. Jurnal Filsafat, 22(3), 247-272.

Ubaidillah, A., Mulyani, S., \& Effendi, D. E. (2013). Makna Keuntungan Bagi Pedagang Kaki Lima ( Studi pada Pedagang Kaki Lima di Bangsri Jepara ). Jurnal Akuntansi \& Investasi, 14(1), 65-77.

Zainuddin, S., \& Isa, C. R. (2019). The role of workplace fairness and information sharing in a budget setting process: An empirical study. Gadjah Mada International Journal of Business, 21(2), 135-158. https://doi.org/10.22146/gamaijb.31133 